\title{
PENGARUH STANDAR KUALITAS TAMAN PENITIAN ANAK (TPA) TERHADAP MOTIVASI DAN KEPUASAAN ORANGTUA (PENGGUNA) UNTUK MEMILIH PELAYANAN TPA YANG TEPAT
}

\author{
Diantifani Rizkita \\ Sekolah Pascasarjana, Universitas Pendidikan Indonesia \\ diantifani@student.upi.edu
}

\begin{abstract}
Abstrak
Taman penitipan anak (TPA) merupakan layanan alternatif yang dapat digunakan oleh orang tua yang bekerja sebagai lembaga yang dapat menggantikan sementara waktu selama orangtua bekerja dalam hal pengasuhan, perawatan, perlindungan dan juga pemberiaan bimbingan terhadap anak, terutama anak dengan rentang usia 0-6 tahun. Pada dasarnya, menitipkan anak di TPA akan sangat membantu, tidak hanya untuk orang tua, tetapi juga bagi anak itu sendiri. Dengan menitipkan anak di TPA, orang tua akan lebih memiliki waktu untuk melakukan kegiatan keseharian (bekerja) dengan perasaan yang aman bahwa anak tetap ada yang mengasuh, menjaga, dan merawat, dan bagi anak itu sendiri TPA dijadikan tempat untuk berinteraksi dan melatih kemandirian agar anak tidak selalu bergantung pada orangtua dalam kesehariannya. Melihat kebermanfaatan dari TPA, menjadikan TPA sebagai lembaga favorit yang diminati keberadaannya oleh orangtua yang membutuhkannya. Penelitian ini menjabarkan indikator yang akan menjadi standar kualitas yang harus dimiliki sebuah TPA agar TPA tersebut dapat dikatakan berkualitas dan dijadikan tempat favorit oleh pengguna. Hasilnya terdapat 6 indikator yang menjadi standar kualitas di sebuah TPA ini; rasio anak dan pengasuh, tenaga pengasuh, kurikulum kegiatan, lingkungan dan fasilitas, serta mitra dengan orangtua. Ke-lima indikator ini kemudian dapat dijadikan pengelola TPA sebagai landasan ketika akan mengembangkan TPA agar lembaga dapat terus maju dan berkembang. Selain itu, indikator ini juga dapat dijadikan orangtua sebagai acuan/referensi ketika mereka akan memilih TPA.
\end{abstract}

Kata Kunci : Taman Penitipan Anak, Manajemen Lembaga, Standar Kualitas, Pelayanan.

\begin{abstract}
Daycare is an alternative service that can be used by parents who work as an institution that can temporarily replace as long as parents work in the care, care, protection and also guidance of children, especially children with age range 0-6 years . Basically, entrusting a child in the daycare will be helpful, not only for the parents, but also for the child himself. By entrusting children in the landfill, parents will have more time to do daily activities (work) with a sense of security that the child is still nurturing, looking after, and caring for, and for the children themselves daycare is a place to interact and train independence for children Not always dependent on the parent in their daily life. Seeing the usefulness of the landfill, making daycare as a favorite institution of interest by parents who need it. This study describes the indicators that will become the quality standard that must be owned by a landfill so that daycare can be said to be qualified and made a favorite place by the user. The result is 6 indicators that become the quality standard in a daycare; Ratio of child and caregiver, caregiver, curriculum of activities, environment and facilities, and partners with parents. These five indicators can then be used as landfill managers as a foundation when
\end{abstract}


developing a landfill so that the institution can continue to grow and develop. In addition, this indicator can also be a parent as a reference / reference when they will choose a landfill.

Keywords: daycare, management instituation, quality standars, services

\section{Pendahuluan}

Menjadi seorang ibu yang bekerja di luar rumah, secara alamiah akan tersita waktuwaktunya untuk pekerjaan yang dilakukannya" (Ahmad \& Hikmah, 2005). Aktifitas ibu yang bekerja di luar rumah, secara kuantitatif dapat mempengaruhi penurunan frekuensi terhadap interaksi antara seorang ibu dengan anaknya, walaupun ini belum tentu menurunkan perhatian seorang ibu terhadap anaknya. Ibu-ibu bekerja atau ibu karir adalah suatu bagian dari kehidupan modern. Hal itu bukan suatu aspek kehidupan yang menyimpang dari kebiasaan, tetapi suatu tanggapan terhadap perubahan sistem sosial, yaitu sesuatu yang untuk dapat memenuhi kebutuhan yang tidak dapat dipenuhi oleh keluarga sebelumnya, yaitu idealnya seorang ibu yang waktunya diperuntukkan dan menjadi pekerja rumah tangga. Hal itu bukan hanya untuk memenuhi kebutuhan-kebutuhan orang tua, tetapi juga dengan banyak cara hal itu dapat menjadi pola yang lebih baik yang cocok untuk mensosialisasikan anak-anak akan peran-peran yang akan mereka laksanakan nantinya, saat anak tidak sedang bersama dengan ibu (Santrock, 2002 ; Hoffman dkk, 1994 ; Rahmadi, 1994).

Namun bukan hal yang tidak dapat dipungkiri dan bahkan dapat membentuk sebuah perasaan yang bersalah dalam diri orang tua, manakala orangtua yang ke duanya bekerja, pada akhirnya harus meninggalkan sementara anaknya saat bekerja dan berjauhan dengan anak-anaknya saat bekerja pula. Perasaan bersalah yang dirasakan orang tua ini dapat dikurangi, pada saat orang tua mulai memberikan perhatian yang lebih besar terhadap bagaimana keadaan anak-anak mereka. Paling tidak dengan masih menyempatkan dan memberikan waktu untuk tetap dapat bersama-sama dengan anak di sela-sela aktifitas dan kesibukan kerjanya. Hal ini dilakukan agar keharmonisan dan kenyamanan pada setiap anggota keluarga tetap selalu terjaga.

Namun hal yang tetap harus menjadi dasar pertimbangan bagi orangtua yang bekerja (terutama ketika ibu juga turut bekerja/ibu karir), siapa yang nantinya akan membantu ibu dalam hal mengasuh, merawat, mendidik, dan melindungi anaknya selama orang tua (ayah dan terutama ibu) tengah melakukan aktifitas kerjanya. Padahal, keberadaan kedua orangtua begitu berperan besar dalam membantu tumbuh kembang seorang anak.

Kaitannya dengan itu, siapa yang layak ditunjuk dan diserahi tanggung jawab untuk dapat menjadi 'keluarga pengganti' sementara. Dimana keluarga pengganti ini dimaksudkan untuk membantu para orang tua yang bekerja dalam hal perawatan, pengasuhan, pendidikan dan perlindungan pada anak sementara waktu.

Peranan keluarga pengganti mengandung makna bukan mengambil alih atau menghilangkan tanggung jawab dan fungsi keluarga sepenuhnya, melainkan hanya mengganti untuk sementara waktu selama orang tua berhalangan dalam memberikan asuhan, dan pendidikan sehingga anak terhindar dari stagnasi proses tumbuh kembang yang pada gilirannya dapat mempengaruhi perkembangan kepribadian anak secara umum (Depdiknas, 2003).

Secara umum tempat yang dapat dijadikan sebagai keluarga pengganti ini antara lain adalah Taman Penitipan Anak (TPA) atau biasa dikenal dengan istilah daycare. Taman penitipan anak saat ini dapat dijadikan salah satu tempat alternatif bagi ibu yang bekerja 
untuk menitipkan anaknya dengan sedikit kekhawatiran dari ibu bekerja tersebut (Supsiolani dkk, 2015 ; Rizkita, 2012). TPA atau yang biasa lebih dikenal dengan sebutan daycare ini adalah wahana pendidikan dan pembinaan kesejahteraan anak yang berfungsi sebagai pengganti keluarga untuk jangka waktu tertentu selama orangtuanya berhalangan atau tidak memiliki waktu yang cukup dalam mengasuh anaknya dikarenakan bekerja atau sebab lainnya yang melakukan pelayanan untuk anak usia 3 bulan sampai dengan usia 6 tahun, yang memberikan layanan untuk anak, meliputi pengembangan perilaku anak, sosialisasi anak, pendidikan, kegiatan bermain, dan pelayanan sosial lainnya (Direktorat PAUD, 2010 ; Depdiknas, 2002 ; Depsos, 2002).

Melihat makna dari taman penitipan anak ini, maka dapat dikatakan bahwa TPA ini akan menjadi "siapa dan dimana" atau mungkin keluarga pengganti sementara yang diharapkan oleh setiap orangtua yang bekerja, terutama ibu. TPA sebagai "keluarga pengganti" diharapkan dapat memberikan pembinaan kesejahteraan dan pelayanan pendidikan bagi anak usia dini untuk mencapai pertumbuhan dan perkembangan yang optimal karena di dalam proses pelaksanaanya TPA memiliki acuan program yang mendasar guna pengembangan proses layanan yang akan diberikannya pada anak yang berada di taman penitipan anak ini (Depdiknas, 2001 ; Wahyuti, 2003).

Pada tahun 1990-an, jauh lebih banyak anak-anak pada usia dini berada di banyak daycare atau taman penitipan anak, dan kira-kira sekitar 2 juta anak baru-baru ini ditempatkan di daycare formal, yang lembaganya telah memiliki izin (Pasmah, 2011 ; Santrock, 2002). Melihat fenomena ini, maka terlihat bahwa daycare adalah lembaga penitipan yang tengah menjadi popular beberapa tahun belakangan ini hingga dengan sekarang.

Perkembangan dari pendirian taman penitipan anak ini, mengacu pada adanya manfaat yang diberikan dari didirikannya taman penitipan anak ini, yakni; di masyarakat Indonesia, terdapat suatu pemahaman bahwa anak yang pernah dididik dan mendapat disiplin ditaman penitipan anak akan menjadikan anak lebih berdisiplin dibandingkan dengan anak yang di didik dirumah, dan memunculkan rasa kepercayaan diri yang tinggi dalam berinteraksi dengan teman maupun orang dewasa yang ada disekitar anak (Wildaniah, 2013 ; Ahmad \& Hikmah, 2005 ; Santrock, 2002).

Dengan menitipkan anak ditaman penitipan anak, orang tua (ibu) akan lebih memiliki waktu untuk melakukan kegiatan keseharian/bekerja dengan perasaan yang aman bahwa anak -anak tetap ada yang mengasuh, menjaga, dan merawat, dan ditaman penitipan anak ini pula anak-anak dapat bertemu dan berinteraksi dengan teman-teman sebayanya, ataupun dengan yang beragam usia, sehingga dapat meningkatkan tingkat interaksi anak secara sosial, karena ketika anak sedang berada ditaman penitipan anak, anak dapat bertemu dengan anak seusianya yang dapat diajaknya bermain, dan melakukan berbagi hal, yang tidak dapat anak rasakan jika anak hanya di rawat oleh asisten rumah tangga (ART) atau baby sitter dirumah.

Taman penitipan anak yang juga berfungsi sebagai tempat pengganti sementara bagi ibu dalam mengasuh anak selama anak dan ibu terpisah secara sementara (Ahmad \& Hikmah, 2005), sebagaimana yang dijabarkan diatas memungkinkan lembaga penitipan anak ini kerap dijadikan solusi yang cukup baik untuk mengatasi permasalahan tersebut.

Taman penitipan anak adalah sebagai pelengkap dan penambah pengalaman hidup bagi anak usia dini untuk menggantikan orangtua dalam memberikan stimulasi yang dapat mengoptimalkan perkembangan dan pertumbuhan anak, namun bukan sebagai pengganti orangtua. Tujuan taman penitipan anak pada hakikatnya adalah memberikan pelayanan, bimbingan dan pendidikan kepada anak usia dini yang dikhawatirkan akan mengalami 
hambatan dalam pertumbuhan dan perkembangannya karena ditinggalkan orangtua (ibu) bekerja ( Desiyanty, 2015 ; Depsos, 2002 ).

Melihat perannya yang cukup penting dalam hal pemegangan peran keluarga pengganti dan tujuan dari taman penitipan anak ini, tidak salah jika seharusnya kualitas dari peningkatan mutu taman penitipan anak terus dikembangkan dan dioptimalkan, sesuai dengan standarnya, agar peranan taman penitipan anak sebagai keluarga pengganti ini dapat terlaksana dan teroptimalkan secara maksimal sesuai dengan perannya.

Penelitian ini mengkaitkan antara standar kualitas yang harus dimiliki sebuah taman penitipan anak dengan kenyataan yang terjadi dilapangan; apakah standar kualitas ini sudah dimiliki oleh taman penitipan anak yang diteliti, sehingga kualitas dari sebuah taman penitipan anak ini, benar-benar dapat dinikmati oleh pengguna yang akan menggunakan taman penitipan anak (TPA) sebagai tempat keseharian, untuk melakukan pelayanan terhadap anak-anak dari pengguna (orangtua) ini, sehingga pengguna dapat mempercayakan anak mereka secara maksimal pada taman penitipan anak yang dituju oleh orangtua sebagai pengguna.

\section{Kajian Teori}

\section{Standar Kualitas Taman Penitipan Anak}

Taman penitipan anak yang berkualitas dapat dilihat dari beberapa indikator yang membentuk kebutuhan dasar dari taman penitipan anak yang diuraikan oleh Ahmad, 2011:29 ; Verity dan Alison, 2010:48 ; Depsos, 2002 ; DeBord, 1987:1-5, diuraikan sebagai berikut :

\section{a. Jumlah Anak}

Rasio jumlah anak dan tenaga pengasuh akan menentukan kualitas pelayanan terhadap anak usia dini di tempat penitipan anak. Usia anak akan menentukan jumlah dari tenaga pengasuh yang kemudian akan mendampinginya, karena penentuan jumlah dari tenaga pengasuh ini disesuaikan dengan tingkat pencapaian perkembangan bagi masing-masing usia anak yang diasuhnya.

Tabel 1.1

Rasio Jumlah Tenaga Pengasuh dan Anak Berdasarkan Usia

\begin{tabular}{|l|l|}
\hline Rentang Usia Anak & \multicolumn{1}{|c|}{ Rasio Jumlah Tenaga Pengasuh } \\
\hline $0-<1$ tahun & 1 tenaga pengasuh $: 4$ anak \\
\hline $1-<2$ tahun & 1 tenaga pengasuh $: 6$ anak \\
\hline $2-<3$ tahun & 1 tenaga pengasuh $: 8$ anak \\
\hline $4-<5$ tahun & 1 tenaga pengasuh : 12 anak \\
\hline $5-<6$ tahun & 1 tenaga pengasuh : 15 anak \\
\hline
\end{tabular}

Sumber : (Depdiknas, 2001).

Rasio tersebut dapat disesuaikan dengan karakteristik anak. Untuk anak dengan usia 0-1 tahun membutuhkan intensitas perhatian yang lebih tinggi dibandingkan dengan usia lainnya karena anak usia ini masih memiliki ketergantunga kepada orang 
dewasa yang ada disekitarnya. Hal ini dapat juga dilakukan untuk menjaga kualitas pelayanan di taman penitipan anak.

b. Kualitas Tenaga Pengasuh

Tenaga pengasuh taman penitipan anak yang berkualitas seharusnya memiliki ilmu dasar tentang penanganan anak yang lebih mendalam, sehingga akan menunjukan perilaku yang hangat, dapat memberikan perhatian, mampu menciptakan kondisi yang menyenangkan dan memahami karakteristik perkembangan anak sehingga pelayanan dan pengasuhan yang dilakukan dapat disesuaikan dengan kebutuhan anak yang dipegangnya.

c. Kurikulum yang Tepat

Beberapa ahli pendidikan dan perkembangan anak mengemukakan terdapat pola pertumbuhan yang cepat pada usia 0-9 tahun, sehingga orangtua dan tenaga pendidik yang memahami perkembangan anak akan merencanakan pendidikan yang tepat bagi anak usia tersebut. Kurikulum yang digunakan di taman penitipan anak adalah yang sesuai dengan perkembangan dan kebutuhan bagi anak itu sendiri sehingga anak akan memiliki pengalaman belajar yang menyenangkan.

d. Lingkungan dan Fasilitas

Lingkungan yang aman, nyaman dan menyenangkan merupakan salah satu bagian penting dalam tempat penitipan anak yang berkualitas. Peralatan bermain yang menjadi salah satu media untuk anak sebaiknya diperhatikan kualitasnya sebaik mungkin (tidak berbahaya, jauh dari zat kimia, selalu bersih, dan aman) agar dapat di pergunakan oleh anak (Christya, 2009). Lingkungan atau fasilitas dari taman penitipan anak yang berkualitas akan menentukan pola bimbingan, stimulasi dan pendidikan yang akan diperoleh anak untuk mencapai perkembangan dan pertumbuhan yang optimal sesuai dengan kebutuhannya.

e. Mitra dengan Orangtua

Fungsi taman penitipan anak adalah membantu orangtua dalam memberikan pengasuhan, pelayanan dan pendidikan bagi anak, sehingga seluruh kegiatan yang dilakukan di tempat penitipan anak perlu dikomunikasikan kepada orangtua. Komunikasi orangtua dengan pengasuh di taman penitipan anak akan memudahkan anak dalam mencapai tingkat perkembanagn dan pertumbuhan pada anak.

Kualitas bagi peningkatan mutu taman penitipan anak ini juga dapat dilihat dari segi komponen kebutuhan yang diharuskan ada untuk sebuah taman penitipan anak, yakni sarana dan prasarana (fasilitas) yang ada di taman penitipan anak, program- program layanan yang diberikan di taman penitipan anak, tenaga pengasuh yang disediakan di taman penitipan anak, dan pengelolaan administrasi yang dilakukan di taman penitipan anak ( Santrock, 2002 ;

Tabel 1.2

Kualitas Taman Penitipan Anak oleh National Association for the Education of Young Children (NAEYC)

\begin{tabular}{|c|l|l|}
\hline No. & Kualitas & \multicolumn{1}{|c|}{ Penjelasan } \\
\hline 1. & Pengasuh & $\begin{array}{l}\text { Para pengasuh harus memperhatikan dan melakukan hal berikut : } \\
\text { a. Pengasuh harus menikmati dan memahami bayi dan balita }\end{array}$ \\
\hline
\end{tabular}




\begin{tabular}{|c|c|c|}
\hline & & $\begin{array}{l}\text { tumbuh dan berkembang. } \\
\text { b. Harus ada cukup orang dewasa untuk bekerja dengan satu } \\
\text { kelompok dan untuk mengurus kebutuhan-kebutuhan } \\
\text { individual anak. Adanya perbandingan yang tepat antara } \\
\text { pengasuh dengan anak. } \\
\text { c. Para pengasuh harus mengamati dan mencatat kemajuan dan } \\
\text { perkembangan setiap anak. }\end{array}$ \\
\hline 2. & $\begin{array}{l}\text { Kegiatan dan } \\
\text { Perlengkapan } \\
\text { Program }\end{array}$ & $\begin{array}{l}\text { a. Lingkungan harus mempermudah pertumbuhan dan } \\
\text { perkembangan balita untuk dapat beraktifitas belajar dan } \\
\text { bermain bersama-sama. } \\
\text { b. Daycare yang baik menyediakan perlengkapan dan bahan } \\
\text { permainan yang sesuai dan memadai, dan mengusahakannya } \\
\text { agar selalu siap untuk digunakan. } \\
\text { c. Bayi dan anak-anak harus dibantu untuk meningkatkan } \\
\text { keterampilan bahasa mereka dan untuk memperluas } \\
\text { pemahaman mereka tentang dunia luar disekitarnya. }\end{array}$ \\
\hline 3. & $\begin{array}{l}\text { Hubungan } \\
\text { Staf dengan } \\
\text { Keluarga dan } \\
\text { Masyarakat }\end{array}$ & $\begin{array}{l}\text { a. Program yang baik harus memperhatikan dan mendukung } \\
\text { kebutuhan-kebutuhan seluruh keluarga. Orang tua harus } \\
\text { dipersilahkan untuk mengamati, mendiskusikan pekerjaan, } \\
\text { mengajukan saran, dan bekerja di dalam kegiatan daycare. } \\
\text { b. Staf di dalam daycare yang baik harus menyadari dan } \\
\text { memberikan sumbangan pada berbagai sumber yang ada di } \\
\text { lingkungan sekitar. Staf harus berbagi informasi tentang } \\
\text { kesempatan-kesempatan untuk melakukan rekreasi dan } \\
\text { pembelajaran dalam lingkungan ini pada keluarga. }\end{array}$ \\
\hline 4. & Fasilitas & $\begin{array}{l}\text { a. Kesehatan anak-anak, staf dan orang tua harus dilindungi dan } \\
\text { ditingkatkan. Staf harus waspada terhadap kesehatan setiap } \\
\text { anak. } \\
\text { b. Fasilitas harus aman bagi anak-anak dan orang dewasa. } \\
\text { c. Lingkungan harus memiliki ruang yang cukup untuk } \\
\text { menampung berbagai kegiatan dan perlengkapan. Secara lebih } \\
\text { spesifik, harus ada minimal } 35 \text { kaki persegi ruang dalam yang } \\
\text { dapat digunakan sebagai ruang permainan dan } 75 \text { kaki persegi } \\
\text { ruang luar per anak. }\end{array}$ \\
\hline
\end{tabular}

Sumber : Santrock, 2002 ; NAEYC, 1997

\section{Metode}

Metode penelitian yang digunakan didalam penelitian ini adalah dengan menggunakan metode penelitian survei (survey design). Survei merupakan satu bentuk teknik penelitian dimana informasi dikumpulkan dari sejumlah sampel berupa orang, melalui pertanyaan-pertanyaan, dan satu cara untuk mengumpulkan data melalui komunikasi dengan individu-individu dalam suatu sampel dimana penelitian survei ini digunakan untuk mengumpulkan data atau informasi tentang populasi yang besar dengan menggunakan sampel yang relatif kecil (Sukmadinata, 2010:82 ; Mustafa, 2001). Dalam 
penelitian ini, survei yang dilakukan digunakan untuk mengambil data secara langsung terhadap civitas akademika (pegawai, dosen dan mahasiswi) yang berstatus sebagai ibu dan memiliki anak dengan rentang usia 0-8 tahun dan juga pengguna TPA yang berada di wilayah Universitas Pendidikan Indonesia ini.

Dari jumlah total civitas akademika Universitas Pendidikan Indonesia yang berjumlah 28.750 terdiri atas a. Mahasiswa 26.989; b. Dosen 1.108; c. 656 (Sumber : BAAK UPI, 2012). Terpilihlah 150 civitas akademika yang masuk dalam kriteria (seorang ibu, memiliki usia produktif 25-40 tahun, dan memiliki anak dengan rentang usia 0-8 tahun) untuk dijadikan sumber informan (sampel) dalam penelitian ini. Dan 32 orang ibu pengguna Tempat Penitipan Anak Laboratorium Percontohan UPI yang turut menjadi sampel guna pengambilan data yang relevan pada penelitian ini.

Teknik pengumpulan data dalam penelitian ini adalah dengan menggunakan kuesioner atau angket dan juga wawancara. Kuesioner atau angket merupakan sejumlah daftar pernyataan atau pertanyaan yang berkaitan dengan penelitian dan diberikan kepada responden untuk diisi agar peneliti mendapatkan informasi yang terkait (Wahyudin \& Agustin, 2010 ; Arikunto, 2006). Teknik analisa data dilakukan dengan teknik insident by insident coding (kejadian per kejadian).

Angket pada penelitian ini berisikan tentang pernyataan dan pertanyaan yang terkait dengan aspek standar kualitas dari sebuah Taman Penitipan Anak, yakni ; 1). Fasilitas/Lingkungan Daycare ( kondisi fisik/sarana prasarana seperti apa yang seharusnya ada di dayacre, ruangan apa saja yang sebaiknya ada di sebuah daycare, sistem keamanan seperti apa yang harus ada di sebuah daycare dan sebagainya). 2). Kualifikasi Tenaga Pengasuh (kualifikasi dari seorang tenaga pengasuh, sikap seorang tenaga pengasuh dan sebagainya. 3). Kurikulum ( terkait waktu layanan, jenis makanan yang diberikan, aktifitas yang diberikan di daycare selama anak berada di daycare dan sebagainya. 4). Administrasi (berkaitan dengan biaya harian dari sebuah tempat penitipan anak, biaya bulanan, biaya masuk, kesepakatan tata tertib dan sebagainya). 5). Mitra Orangtua, apa yang taman penitipan anak lakukan untuk meningkatkan peran orangtua dalam pengembangan taman penitipan anak ini ( kesepakatan tata tertib antara pengguna dan TPA, kegiatan parenting, home visit dsb ).

\section{Contoh isian angket:}

Pertanyaan Apa yang anda bayangkan, jika anda membayangkan sebuah tempat penitipan anak? Jawaban (15 November 2012 seorang Ibu berinisial A.N usia 35 tahun) tempat yang bisa digunakan untuk anak-anak beristirahat, makan siang disana, mandi juga bersama-sama dengan teman-teman yang lainnya. Sehingga kami para ibu bekerja merasa terbantu dengan adanya tempat penitipan anak.

Kemudian jawaban-jawaban dari angket ini dianalisa oleh peneliti dan kemudian diberikan kode-kode untuk membantu peneliti dalam hal penemuan informasi yang dibutuhkan untuk menjawab rumusan penelitian yang dimaksudkan oleh peneliti. Misal : tempat yang biasa digunakan anak-anak beristirahat (kode : fasilitas), makan siang disana (kode : kurikulum kegiatan di TPA ), mandi juga (kode : kurikulum kegiatan di TPA), bersama-sama dengan teman-teman yang lainnya (kode : menjalin pertemanan), sehingga kami para ibu bekerja merasa terbantu dengan adanya tempat penitipan anak (kode : fungsi TPA, kualitas tenaga pengasuh).

Peng-coding-an ini dilakukan pada semua hasil jawaban pada angket-angket yang terisi, begitupun dengan hasil dari wawacaranya dicantumkan kode-kode guna pengidentifikasian lebih lanjut mengenai data-data yang diambil dilapangan. 
Dengan melakukan coding ini, dapat membantu peneliti menemukan jawaban refleksi akan penelitian ini, sehingga tujuan dari penelitian ini, yakni menjabarkan standar kualitas taman penitipan anak ini dapat ditemukan, sehingga hasilnya nanti peneliti dapat mengkombinasikannya dengan teori-teori sebelumnya atau memungkinkan peneliti dapat menemukan teori baru (grouded teori) yang dibentuk dalam coding data-data yang ditemukan peneliti ini.

\section{Hasil}

Hasil yang ditemukan dalam penelitian ini adalah berupa diagram presentase yang menyatakan beberapa hal, terkait dengan standar kualitas taman penitipan anak, yang akan menarik minat orangtua (pengguna), ketika akan menitipkan anak ditaman penitipan anak. Terdapat 5 faktor indikator yang berkaitan dengan standar kualitas sebuah taman penitipan anak yang diharapkan pengguna, yakni adanya 1). Jumlah rasio yang jelas antara anak yang diasuh dengan tenaga pengasuh; 2). Tenaga pengasuh yang tentu saja harus memiliki kemampuan kerja yang mumpuni untuk melakukan pelayanan yang baik ditaman penitipan anak tersebut; 3). Aktifitas kegiatan (jadwal) yang terstruktur, terencana dan terarah, serta memiliki acuan yang jelas terhadap apa yang akan dikerjakan tenaga pengasuh dan anak ditaman penitipan anak tersebut; 4). Fasilitas dan lingkungan harus benar-benar aman, nyaman, dan terjangkau oleh pengguna taman penitipan anak tersebut; dan yang terakhir adalah 5). Keterlibatan pengelola, tenaga pengasuh dan SDM ditaman penitipan anak, yang terus dapat menjalin komunikasi yang baik pada pengguna, sebagai dasar adanya kesinambungan antara taman penitipan anak dan rumah.

Kelima indikator ini memiliki peringkat masing-masing yang menjadi diminati oleh pengguna, saat pengguna pertama kali melihat sebuah taman penitipan anak untuk menitipkan anak-anak. Hal ini ditunjukan dengan diagram berikut ini :
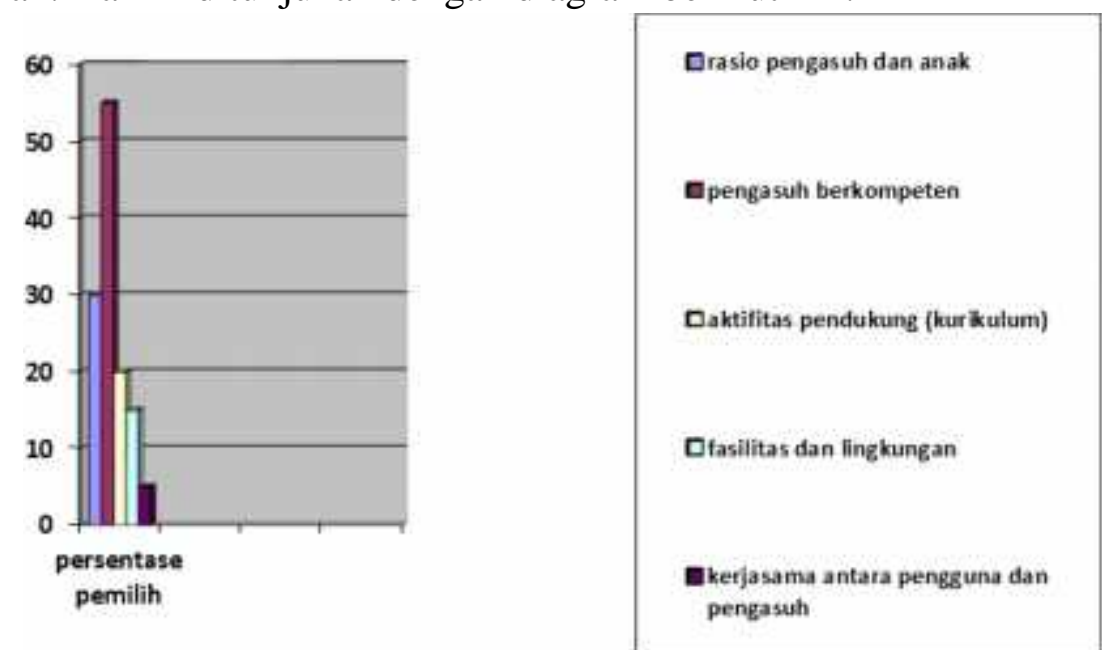

\section{Diagram 1.1}

\section{Peringkat Ke-5 Indikator Standar Kualitas TPA Dimata Pengguna} ( yang lebih diminati )

Dari 5 indikator standar kualitas TPA ini juga ditemukan, sub-sub indikator yang diminati pengguna saat mereka melihat taman penitipan anak. Penjabaran sub-sub indikator tersebut dapat dilihat dalam diagram berikut :

a. Rasio Pengasuh dan Anak

Dalam melakukan praktek pelayanan pada anak ditaman penitipan anak perbandingan antara pengasuh dan anak, akan sangat diperhatikan oleh pengguna saat 
pengguna memilih TPA, hal ini dikarenakan untuk memastikan pengguna (orangtua) apakah saat dititipkan di TPA, anaknya ini ada yang bertanggung jawab tentang segala hal pada diri anak (siapa yang kemudian akan mengajaknya bermain, menemaninya istirahat siang, saat makan, dan saat anaknya membutuhkan pertolongan, saat anak sedang kesulitan).

Dibandingkan dengan keahlian, standar kualifikasi dan cara kerja pegasuh dalam melayani anak, orangtua sebagai pengguna lebih, mengkhawatirkan apakah rasio antara anak dan pengasuh benar-benar diperhatikan saat proses layanan di TPA dilakukan. Hal ini terlihat dalam diagram berikut ini:

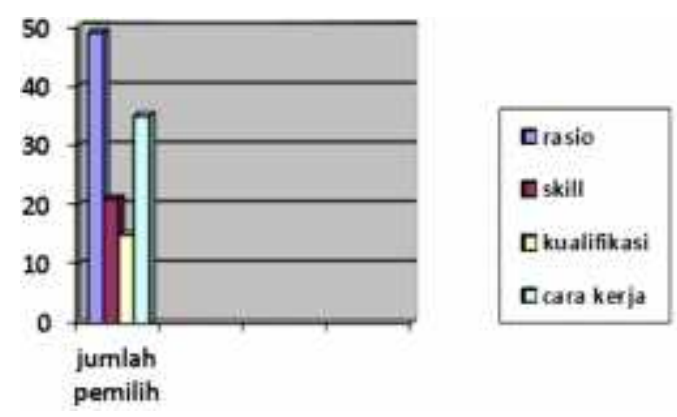

Diagram 1.2

Presentase Rasio Pengasuh Diminati Pengguna dibanding dengan Faktor Pendukung lain yang Dimiliki Pengasuh

b. Kompetensi Tenaga Pengasuh

Hasil penelitian terhadap 120 responden perwakilan dari civitas akademika di Universitas Pendidikan Indonesia terhadap pengembangan kompetensi untuk tenaga pengasuh yang berada di Taman Penitipan Anak di Universitas Pendidikan Indonesia ini menyatakan sebagai berikut:

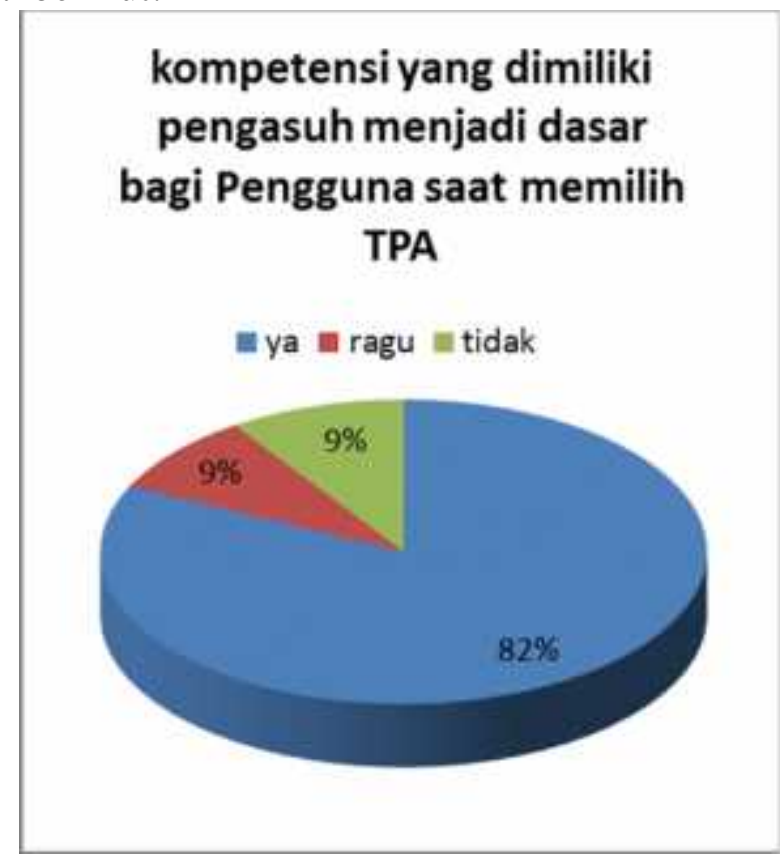

Diagram 1.3

Pertimbangan Pengguna pada Kompetensi yang Dimiliki Pengasuh 

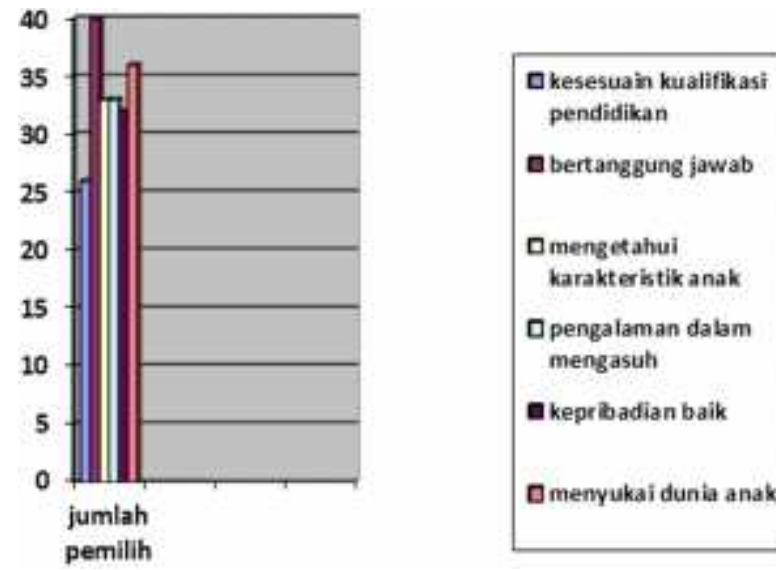

Diagram 1.4

\section{Kompetensi yang Harus dimiliki Tenaga Pengasuh menurut Pengguna}

c. Kurikulum TPA

Kurikulum yang dimaksudkan di TPA, bukanlah mendasarkan pada kurikulum pembelajaran seperti di sekolah formal, melainkan bentuk kegiatan (program) atau aktifitas yang perlu dilakukan selama anak berada di TPA, sehingga pengguna merasa yakin bahwa di TPA tidak sebatas pada pengasuhan dan perawatan anak semata. 


\section{Program TPA yang menjadi daya tarik Pengguna}

- menyatakan bahwa layanan perawatan pada anak merupakan program layanan yang dapat diberikan di sebuah taman penitipan anak.

= menyatakan bahwa layanan pengasuhan pada anak merupakan program layanan yang dapat diberikan di sebuah taman penitipan anak.

= menyatakan bahwa layanan perlindungan pada anak merupakan program layanan yang dapat diberikan di sebuah taman penitipan anak.

= menyatakan bahwa layanan kegiatan belajar merupakan program layanan yang dapat diberikan di sebuah taman penitipan anak.

w menyatakan bahwa layanan pemeriksaan kesehatan pada anak merupakan program layanan yang dapat diberikan di sebuah taman penitipan anak.

= menyatakan bahwa layanan pemberian gizi yang seimbang untuk anak merupakan program layanan yang dapat diberikan di sebuah taman penitipan anak

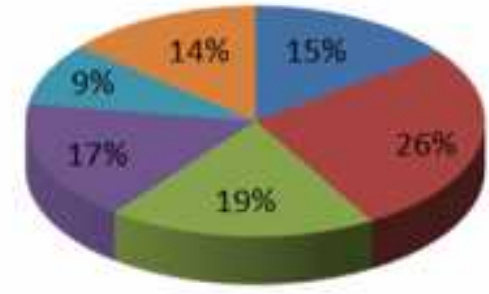

\section{Diagram 1.5}

\section{Program Kegiatan yang menjadi Daya Tarik Pengguna di TPA}

d. Lingkungan dan Fasilitas

Lingkungan harus mempermudah pertumbuhan dan perkembangan balita untuk dapat beraktifitas belajar dan bermain bersama-sama. Taman penitipan anak (TPA) yang baik menyediakan perlengkapan dan bahan permainan yang sesuai dan memadai, dan mengusahakannya agar selalu siap untuk digunakan. Fasilitas harus aman bagi anak-anak dan orang dewasa. Lingkungan harus memiliki ruang yang cukup untuk menampung berbagai kegiatan dan perlengkapan.

Sarana dan prasarana merupakan komponen kebutuhan dasar (bagian indikator) yang harus dipersiapkan seoptimal dan semaksimal mungkin karena sarana dan prasarana merupakan salah satu faktor yang dapat menarik daya tarik bagi anak untuk menyukai sebuah tempat terutama tempat baru. Dan juga menjadi daya tarik bagi orangtua yang akan menitipkan anak - anak ditaman penitipan anak ini.

Terdapat beberapa sub indikator yang mempengaruhi lingkungan dan fasilitas taman penitipan anak yang akan menjadi daya tarik pengguna saat ia harus memilih sebuah taman penitipan anak. Hal ini dapat dilihat dalam diagram berikut ini : 
Syarat dari Fasilitas dan Lingkungan yang ada di TPA

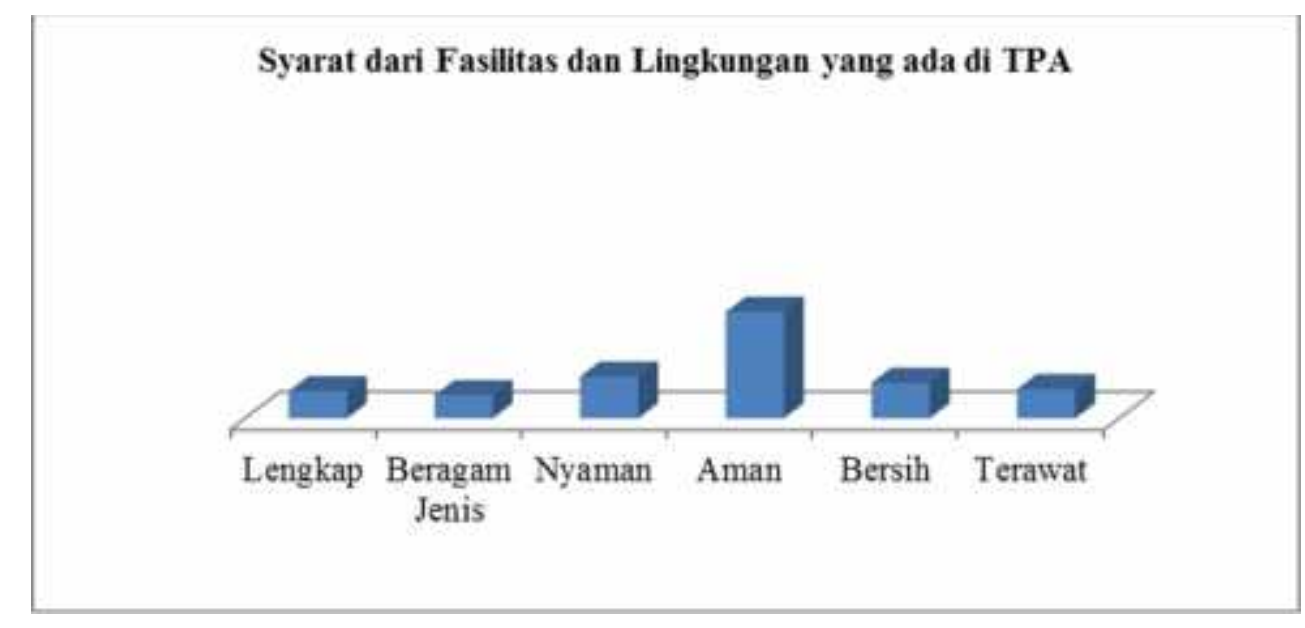

Diagram 1.6

Prasyarat Lingkungan dan Fasilitas yang Diharapkan oleh Pengguna TPA

\section{Peringkat Kebutuhan Sarana dan Prasarana Yang}

diutamakan di TPA

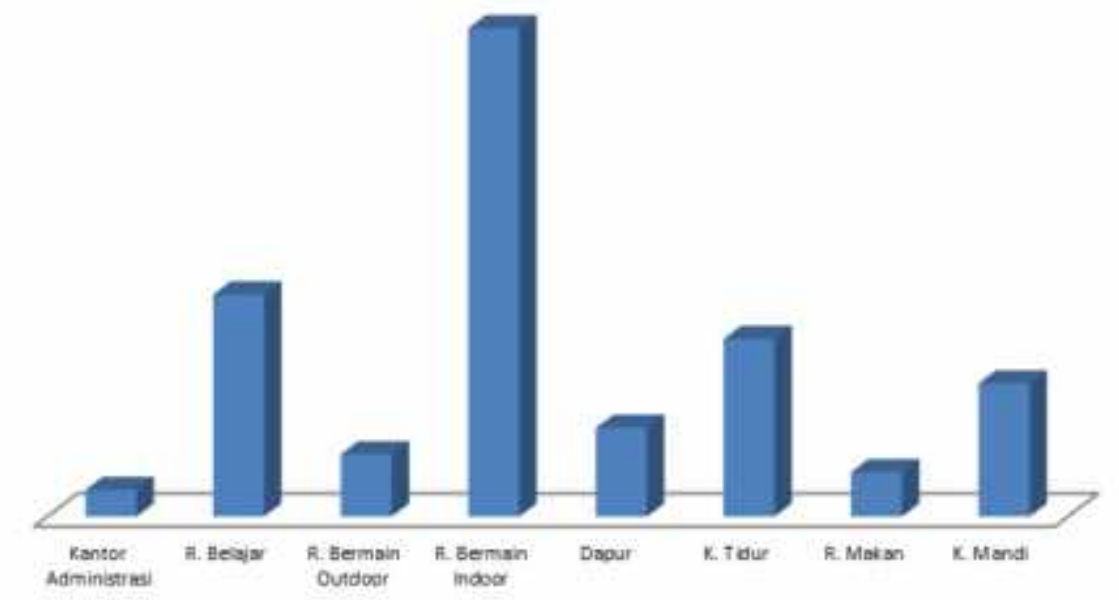

\section{Diagram 1.7}

Kebutuhan Lingkungan dan Fasilitas yang Utama di TPA

e. Kerjasama Orangtua dan TPA

Pada dasarnya banyak cara yang dapat di tempuh untuk menjalin kerjasama antara orangtua dengan lembaga TPA antara lain:

1) Home Visit

Pelaksanaan kunjungan kerumah anak ini akan berdampak sangat positif diantaranya :

a) Kunjungan melahirkan perasaan pada anak bahwa lembaga tetap memperhatikan dan mengawasinya 
b) Kunjungan tersebut memberikan kesempatan kepada pendidik dan pengasuh untuk melihat sendiri dan mengobservasi langsung pembiasaan yang dilakukan anak dan orangtua dirumah dalam hal kepengasuhan, perawatan dan bimbingan lainnya.

c) Tenaga pendidik maupun pengasuh dapat berkesempatan untuk memberikan penerangan kepada orang tua tentang pendidikan yang baik, cara-cara menghadapi masalah-masalah yang sedang di alami anak, ketika orangtua mengalami kesulitan saat mengasuh anak dirumah

d) Hubungan antara orang tua dengan lembaga akan bertambah erat

e) Kunjungan dapat memberikan motivasi kepada orang tua anak untuk lebuh terbuka dan dapat bekerjasama dalam upaya memajukan pendidika anaknya.

2) Mengundang Orangtua ke Sekolah

Memfasilitasi berbagai kegiatan yang diselenggarakan oleh lembaga TPA sendiri yang dapat dimungkinkan untuk dihadiri oleh orang tua, maka akan positif sekali bila orang tua di undang untuk datang kesekolah seperti class meeting, pameran, performance day dan lainnya.

\section{3) Case coference}

Merupakan rapat atau konferensi tentang kasus. Pembahasan kesepakatan tata tertib lembaga TPA dapat disampaikan dalam kegiatan ini, sehingga akan memperkuat dan memperjelas kesepakatan yang terjadi antara pengguna dengan pihak TPA tentang praktek pelayanan yang akan dilakukan di TPA.

4) Forum Orangtua Siswa dan Tenaga Pendidik/Kependidikan

Forum ini merupakan organisasi antara orang tua murid atau wali murid dan pengelola, pendidik maupun pengasuh. Sehingga keterlibatan dan komunikasi dari masing-masing pihak tetap berjalan dengan baik.

5) Komunikasi melalui Redaksi Surat

Surat menyurat diperlukan terutama pada waktu-waktu yang sangat diperlukan bagi perbaikan pendidikan anak didik, seperti sarat peringatan dari guru kepada orang tua agar anaknya lebih giat belajar.

6) Adanya Laporan Perkembangan Anak

Laporan perkembangan dapat diberikan pada orangtua secara harian, mingguan dan juga dalam kurun waktu bulanan ( per 3 bulan atau per 6 bulan ) tergantung situasi keadaan yang sifatnya urgent untuk segera diinformasikan. Laporan perkembangan diberikan melalui buku penghubung maupun grup di media elektronik. Lembaga TPA dapat memberi surat peringatan atau meminta bantuan jika hasil laporan perkembangan anak kurang baik, atau sebaliknya jika anaknya memiliki keistimewaan melalui tenaga ahli jika pihak TPA dan orangtua belum menemukan solusi tepat tentang perkembangan anak yang sesuai dengan masa-masa perkembangannya.

\section{Simpulan}

Kebutuhan orang tua untuk menitipkan anaknya saat mereka bekerja terus meningkat. Banyak orang tua merasa tidak yakin dengan jenis tempat penitipan anak yang mereka cari. Seperti apa tempat penitipan anak yang tersedia untuk orang tua, dan keuntungan dan kerugian apa yang didapatkan dari pelayanan seperti ini?. 
Jenis penitipan anak yang tersedia untuk anak sangat beragam di berbagai daerah. Tempat penitipan anak pun kini muncul dengan format seperti taman kanak-kanak, taman bermain anak, playgroup, dan bentuk lainnya. Untuk perawatan di rumah, ada yang menawarkan jasa pengasuhan anak untuk orang tua yang sibuk bekerja dan hanya punya sedikit waktu untuk mengurus anak.

Banyak orang tua yang sibuk bekerja memilih untuk memasukkan anak mereka ke tempat penitiipan anak yang dilengkapi dengan fasilitas tertentu seperti pembekalan pelatihan keagamaan, mengasah keterampilan berhitung dan membaca, maupun tempat pengembangan bakat seni dan olahraga. Akan tetapi, dari semua fasilitas yang diberikan oleh tempat penitipan anak, terdapat beberapa hal penting yang harus diperhatikan orangtua sebelum menentukan pilihan yang tepat untuk menitipkan anak

Beberapa hal (indikator) yang perlu di pertimbangkan diantaranya; Memastikan tempat penitipan anak ini memiliki surat izin usaha dan melakukan pemeriksaan kesehatan, keamanan, kebersihan, ketertiban karyawan dan program-program yang ditawarkan (Kurikulum Kegiatan yang Terstruktur); Memastikan bahwa staf pengajar dan pengasuh anak telah menjalani basic training dan pengalaman yang cukup untuk membantu menstimulasi pertumbuhan anak (Tenaga Pengasuh Berkompeten).

Para orangtua juga dapat mengecek kualitas tempat penitipan anak dengan melihat tingkat akreditasi. Memastikan juga taman penitipan anak ini menyediakan mainan yang sesuai dengan umur anak (Lingkungan yang Baik), jadwal bermain dan belajar yang berkualitas, serta terciptanya interaksi yang harmonis dan hangat antara pengasuh dengan anak-anak merupakan bukti nyata bahwa tempat ini berkualitas dan layak untuk dipertimbangkan (Kerjasama antara TPA dengan pihak lain).

Pada dasarnya taman penitipan anak yang baik dengan memenuhi kualifikasi di atas biasanya memasang tarif lebih mahal, karena memiliki staf pendidik professional yang membutuhkan gaji yang lebih besar dan peralatan bermain dan fasilitas pemeliharaan lainnya yang membutuhkan biaya yang cukup tinggi. Sehingga orangtua juga dapat memastikan bahwa mereka memiliki pembiayaan yang cukup untuk mendapatkan taman penitipan anak yang berkualitas yang dibutuhkan oleh orangtua.

Apapun pilihan orangtua untuk menggunakan jasa taman penitipan anak di kala orangtua sibuk bekerja, memastikan anak untuk mendapatkan yang terbaik dari segi pendidikan, pengasuhan, kebersihan, kesehatan dan keamanan ditaman penitipan anak tersebut merupakan hal yang tepat yang juga dapat dilakukan orangtua, untuk menitipkan anak di TPA yang berkualitas, yang diminati oleh orangtua ini. 


\section{Daftar Pustaka}

Ahmad, K \& Hikmah. (2005). Perlindungan dan Pengasuhan Anak Usia Dini. Jakarta: Depdiknas, Direktorat Jenderal Pendidikan Tinggi, Direktorat Pembinaan Pendidikan Tenaga Kependidikan dan Ketenagaan Perguruan Tinggi.

Ahmad, S. (2011). Perkembangan Anak Usia Dini. Jakarta: Kencana Prenada Media Group.

Arikunto, S. (2006). Prosedur Penelitian Suatu Pendekatan Praktik, Ed Revisi VI. Jakarta: Penerbit PT Rineka Cipta.

Christya, Ningrum Mettyana. (2009). Pendidikan Anak Usia Dini dan Fasilitas Taman Penitipan Anak Di Semarang. Tesis Magister pada Jurusan Arsitektur Fakultas Teknik Universitas Diponegoro. Tidak diterbitkan.

DeBord, Karen (1987). Quality Child Care. USA : Cooperative Extension Service North Carolina.

Departemen Pendidikan Nasional. (2001). PedomanPenyelenggaraan Pendidikan pada Taman Penitipan Anak. Jakarta : Direktorat Kementerian Pendidikan dan Kebudayaan Republik Indonesia.

Departemen Pendidikan Nasional. (2002). Direktori Taman Penitipan Anak Di Indonesia. Jakarta: Direktorat PAUD Depdiknas.

Departemen Pendidikan Nasional. (2003). Pedoman Rintisan Program Taman Penitipan Anak. Jakarta: Ditjen PLSP Depdiknas RI.

Departemen Sosial. (2002). Pedoman Penyelenggaraan Pelayanan Sosial Anak di Taman Penitipan Anak (TPA). Jakarta: Ditjen Bina Kesejahteraan Sosial Depsos RI.

Desiyanty,dkk. (2015). Pelayanan Taman Penitipan Anak Dalam Pengasuhan Anak di TPA LKIA Pontianak. Jurnal Tesis PMIS-PSS UNTAN.

Direktorat Pendidikan Anak Usia Dini. (2010). Pedoman Teknis Penyelenggaraan Taman Penitipan Anak. Jakarta: Direktorat Pennididikan Anak Usia Dini Direktorat Jenderal Pendidikan Nonformal dan Informal.

Hoffman, Lois, Paris, Scott, \& Hall, Elizabeth. (1994). Development Psychology Today, Sixth Edition, New York: McGraw-Hill Book Co.

Mustafa, Z. (2001). Pengantar Statistik Terapan Untuk Ekonomi, Edisi kedua. Yogyakarta: UII Press.

Pasmah, D. (2011). Eksistensi Taman Penitipan Anak Sebagai Satuan Pendidikan Nonformal. Jurnal Ilmu Pendidikan UNHAS, hlm 13-17.

Rahmadi.(1994). Pengaruh Ibu Yang Bekerja di Luar Rumah Tangga Terhadap Prestasi Belajar Anak di SD-Studi di Kelurahan Bangka Belitung Pontianak Selatan. Tesis. Pontianak : FISIP UNTAN.

Rizkita, D.(2012). Pengembangan Kebutuhan Taman Penitipan Anak di Universitas Pendidikan Indonesia. Skripsi. Bandung : PGPAUD FIP UPI.

Santrock, J.W. (2002). Life Span Development-Perkembangan Masa Hidup. Jakarta: Penerbit Erlangga.

Sukmadinata, N.S. (2010). Metode Penelitian Pendidikan. Bandung: PT Remaja Rosdakarya.

Supsiolani ,dkk. (2015). Eksistensi Taman Penitipan Anak dan Manfaatnya Bagi Ibu Rumah Tangga yang Bekerja. Jurnal Pendidikan Ilmu-Ilmu Sosial No.7. Vol.2 hlm 119-124.

Verity, Barr.C \& Alison, Garnham. (2010). Childcare: A Review of Parents Want. Journal and Education.University of Plymouth. 
Wahyudin, U \& Agustin, M. (2010). Penilaian Perkembangan Anak Usia Dini-Panduan untuk Guru, Tutor, Fasilitator, Pamong Belajar, dan Pengelola Pendidikan Anak Usia Dini. Bandung: CV Falah Production.

Wahyuti, T. (2003). Posisi Strategis Taman Penitipan Anak. Jurnal Ilmiah PADU. No. 02. Vol. 2 hlm. 28-37.

Wildaniah, F. (2013). Program Bimbingan Untuk Mengembangkan Perilaku Prososial pada Anak Usia Dini Melalui Bermain Di TPA Taman ISOLA. Tesis. Universitas Pendidikan Indonesia. 